\title{
Stereotactic body radiotherapy (SBRT) in patients with lung metastases - prognostic factors and long-term survival using patient self-reported outcome (PRO)
}

Kerstin A. Kessel ${ }^{1,2,3^{*+}}$ D, Rebekka C. E. Grosser ${ }^{1 \dagger}$, Kim Melanie Kraus ${ }^{1}$, Hans Hoffmann ${ }^{4}$, Markus Oechsner ${ }^{1}$ and Stephanie E. Combs $s^{1,2,3}$

\begin{abstract}
Objectives: The present study aims to evaluate long-term side-effects and outcomes and confirm prognostic factors after stereotactic body radiotherapy (SBRT) of pulmonary lesions. This is the first work that combines the investigated data from patient charts and patient-reported outcome (PRO) up to 14 years after therapy.

Materials and methods: We analyzed 219 patients and 316 lung metastases treated between 2004 and 2019. The pulmonary lesions received a median dose and dose per fraction of 35 Gy (range: 14-60.5 Gy) and 8 Gy (range: 3-20 Gy) to the surrounding isodose. During the last 1.5 years of monitoring, we added PRO assessment to our follow-up routine. We sent an invitation to a web-based survey questionnaire to all living patients whose last visit was more than 6 months ago.

Results: Median OS was 27.6 months. Univariate analysis showed a significant influence on OS for KPS $\geq 90 \%$, small gross tumor volume (GTV) and planning target volume (PTV), the absence of external metastases, $\leq 3$ pulmonary metastases, and controlled primary tumor. The number of pulmonary metastases and age influenced local control (LC) significantly.

During follow-up, physicians reported severe side-effects $\geq$ grade 3 in only $2.9 \%$ within the first 6 months and in $2.5 \%$ after 1 year. Acute symptomatic pneumonitis grade 2 was observed in $9.7 \%$, as grade 3 in $0.5 \%$.

During PRO assessment, 39 patients were contacted, 38 patients participated, 14 participated twice during follow-up. Patients reported 15 cases of severe side effects (grade $\geq 3$ ) according to PROCTCAE classification. Severe dyspnea $(n=$ 6) was reported mostly.

\footnotetext{
*Correspondence: kerstin.kessel@tum.de

${ }^{\dagger}$ Kerstin A. Kessel and Rebekka C. E. Grosser contributed equally to this work.

'Department of Radiation Oncology, Klinikum rechts der Isar, Technical University of Munich (TUM), Ismaninger Straße 22, 81675 Munich, Germany

${ }^{2}$ Institute of Radiation Medicine (IRM), Helmholtz Zentrum München, Neuherberg, Germany

Full list of author information is available at the end of the article
}

(c) The Author(s). 2020 Open Access This article is licensed under a Creative Commons Attribution 4.0 International License, which permits use, sharing, adaptation, distribution and reproduction in any medium or format, as long as you give appropriate credit to the original author(s) and the source, provide a link to the Creative Commons licence, and indicate if changes were made. The images or other third party material in this article are included in the article's Creative Commons licence, unless indicated otherwise in a credit line to the material. If material is not included in the article's Creative Commons licence and your intended use is not permitted by statutory regulation or exceeds the permitted use, you will need to obtain permission directly from the copyright holder. To view a copy of this licence, visit http://creativecommons.org/licenses/by/4.0/ The Creative Commons Public Domain Dedication waiver (http://creativecommons.org/publicdomain/zero/1.0/) applies to the data made available in this article, unless otherwise stated in a credit line to the data. 
(Continued from previous page)

Conclusion: We could confirm excellent local control and low toxicity rates. PROs improve and complement follow-up care. They are an essential measure in addition to the physician-reported outcomes. Future research must be conducted regarding the correct interpretation of PRO data.

Keywords: Patient-reported outcome, PRO, Outcomes, Survival, Toxicity, Lung metastasis, Stereotactic body radiotherapy, SBRT

\section{Introduction}

Lung metastases represent one of the largest groups of metastases. They can be found in more than $50 \%$ of cancer patients [1]. Whereas for patients with aggressive metastatic spread, systemic therapy remains the treatment of choice for patients with a low metastatic burden, referred to as oligometastatic (OM) disease, local treatment is favored. Initially, resection was the treatment of choice when technically feasible. In cases where surgery cannot be performed due to the irresectability of the tumor, insufficient medical patient conditions, or patient refusal, stereotactic body radiation therapy (SBRT) reveals a noninvasive alternative treatment [2-6]. Generally, based on the emerging data on SBRT, it can even be considered equieffective as a local treatment alternative to surgery [7]. Keeping in mind that SBRT is non-invasive, quick initiation of systemic treatment is possible.

SBRT delivers a hypofractionated dose to the target volume while sparing surrounding tissue. There have already been published various retrospective studies focusing on local control, survival, and severe toxicities [5, 8-11]. However, the optimal prescription dose still needs further investigation. Former studies have proven that biologically effective doses (BED) of over 105 Gy are required for increased local control rates [7, 12]. When delivering an increased fraction dose to the tumor, the risk of normal tissue toxicity can increase. For patients with severe comorbidities and reduced pulmonary function, SBRT with lower fraction doses might be beneficial, as shown for non-small cell lung cancer (NSCLC) [13].

Outcome predictive factors such as the number and pattern of metastases $[14,15]$, target volume size [15, 16], a BED over 90 Gy [16], absence of previous systemic therapy [5], no occurrence of new metastases during follow up [17], and an excellent overall condition [13, 16] have been identified in former studies.

Health care profits increasingly by technical advances. For oncology patients, modern documentation methods, such as apps and web-based solutions, support treatment, and follow-up care. Recent studies also showed the effect of increasing overall survival and quality of life $[18,19]$. Patientreported outcome (PRO) is of increasing interested in completing continuous health information [20-22].

The present study aims to evaluate long-term sideeffects and outcomes and confirm prognostic factors after SBRT of pulmonary lesions. This is the first work that combines the investigated data from patient charts and PRO up to 14 years after therapy.

\section{Patients and methods Patients}

Between 2004 and August 2019, 219 patients and 316 lung metastases were treated consecutively at the Department of Radiation Oncology at the Klinikum rechts der Isar, Munich. Exclusion criteria were radiotherapy (RT) with a simultaneously integrated boost, radiosurgery, or early termination of treatment. Data was collected retrospectively and documented in the institutional database. The local ethics committee of the Medical Faculty of the Technical University München (TUM) approved the study (vote numbers: 257/16, 438/16).

The median age at SBRT was 68 years (range 6-91). Gender distribution was about 3:2 (male:female), see patient characteristics (Table 1). Of all, 62 (19.6\%) patients had multiple SBRTs of pulmonary metastases.

\section{Treatment planning and radiotherapy}

All patients received SBRT. Until 2015, vacuum couch and low-pressure foil (Medical Intelligence $\mathrm{GmbH}$, Schwabmünchen, Germany) ensured immobilization. Since then, abdominal compression was used. When needed, further movement reduction was achieved by administering oxygen to the patient or using abdominal pressure. Before 2010, patients received a conventional computed tomography (CT) for treatment planning, since then 4D-CT were acquired additionally to account for tumor motion adequately. Setup verification was accomplished by onboard cone-beam CT (CBCT) before irradiation.

For all treatment concepts, both organs at risk (OAR) and gross tumor volume (GTV) were defined in the contrast-enhanced treatment planning CT. In 30 (9.5\%) cases, positron emission tomography (PET) imaging was performed additionally. The planning target volume (PTV) resulted from the GTV with an additional margin of $5-10 \mathrm{~mm}$. In cases where a $4 \mathrm{D}-\mathrm{CT}$ was acquired the tumor (GTV) was delineated in all breathing phases resulting in an internal target volume (ITV); the PTV resulted then from the ITV $+5 \mathrm{~mm}$. Additionally, a margin up to $5 \mathrm{~mm}$ was added, resulting in the PTV. SBRT was 
Table 1 Patient characteristics of 219 patients and 316 lesions

\begin{tabular}{|c|c|c|c|}
\hline & $\mathrm{n}$ & $\%$ & Median (range) \\
\hline \multicolumn{4}{|l|}{ Gender } \\
\hline Female & 90 & 41.1 & \\
\hline Male & 129 & 58.9 & \\
\hline Age at RT [years] & & & $68(6-91)$ \\
\hline \multicolumn{4}{|l|}{ Primary tumor type } \\
\hline NSLC & 56 & 17.7 & \\
\hline CRC & 93 & 29.4 & \\
\hline Melanoma & 11 & 3.5 & \\
\hline Breast Cancer & 20 & 6.3 & \\
\hline Others & 136 & 43.0 & \\
\hline \multicolumn{4}{|l|}{ Number of pulmonary METs } \\
\hline$\leq 3$ & 203 & 64.2 & \\
\hline$>3$ & 113 & 35.8 & \\
\hline \multicolumn{4}{|l|}{ MET location } \\
\hline Central & 34 & 10.8 & \\
\hline Upper lobe & 130 & 41.1 & \\
\hline Middle lobe & 23 & 7.3 & \\
\hline Lower lobe & 129 & 40.8 & \\
\hline \multicolumn{4}{|l|}{ Laterality } \\
\hline Right & 169 & 53.5 & \\
\hline Left & 145 & 45.9 & \\
\hline Bilateral & 2 & 0.6 & \\
\hline \multicolumn{4}{|l|}{ Extra thoracic MET } \\
\hline Yes & 131 & 41.5 & \\
\hline No & 185 & 58.5 & \\
\hline \multicolumn{4}{|l|}{ KPS [\%] at RT } \\
\hline 100 & 8 & 2.5 & \\
\hline 90 & 141 & 44.6 & \\
\hline 80 & 137 & 43.4 & \\
\hline 70 & 22 & 7.0 & \\
\hline 60 & 7 & 2.2 & \\
\hline 50 & 1 & 0.3 & \\
\hline \multicolumn{4}{|l|}{ Prior thorax RT } \\
\hline Yes & 87 & 27.5 & \\
\hline No & 229 & 72.5 & \\
\hline \multicolumn{4}{|l|}{ CHT between MET diagnosis and SBRT } \\
\hline Yes & 58 & 18.4 & \\
\hline No & 258 & 81.6 & \\
\hline $\begin{array}{l}\text { Time primary diagnosis until MET diagnosis } \\
\text { [months] }\end{array}$ & & & $30.9(0-265.9)$ \\
\hline Time MET diagnosis until RT [months] & & & $1.7(0-127.3)$ \\
\hline PTV [ml] & & & $28.8(2.0-517.0)$ \\
\hline GTV [ml] & & & $5.4(0.1-217.6)$ \\
\hline
\end{tabular}

NSCLC Non-small cell lung cancer, CRC Colorectal carcinoma, KPS Karnofsky performance score, RT Radiotherapy, CHT Chemotherapy, MET Metastasis, PTV Planning target volume, GTV Gross tumor volume delivered with a Clinac Trilogy linear accelerator (Varian Medical Systems, Palo Alto, CA, USA). The pulmonary lesions were treated with a median dose and dose per fraction of $35 \mathrm{~Gy}$ (range: 14-60.5 Gy) and $8 \mathrm{~Gy}$ (range: 3-20 Gy) to the surrounding isodose.

For better comparison of the transmitted doses, we calculated the $\mathrm{BED}_{10 \text { iso }}$ and $\mathrm{BED}_{10 \mathrm{PTVmean}}$ doses, assuming an $a / \beta$ of 10 . $B E D_{10 \text { iso }}$ is calculated from the $60 \%$ isodose level, $\mathrm{BED}_{10 \mathrm{PTV} \text { mean }}$ from the mean PTV dose. The median $\mathrm{BED}_{10 \text { iso }}$ was $33.0 \mathrm{~Gy}$ (range: 11.2-126.0); the median $\mathrm{BED}_{10 \mathrm{PTV} \text { mean }}$ dose was $106.7 \mathrm{~Gy}$ (range: 29.1-258.9).

\section{Follow-up and patient-reported outcome (PRO)}

Patients were enrolled in a tight follow-up regimen with the first follow-up after 6-8 weeks, including contrastenhanced CT as well as clinical assessment. Further examinations were scheduled after 3 months during the first year, and in 6 to 12-months intervals thereafter depending on the prognosis or as clinically needed. All decisions about further therapies were made on an interdisciplinary basis. Symptoms and toxicity before SBRT and during follow-up were graded according to CTCAE scores (Common Terminology Criteria for Adverse Events, Version 4.03). Depending on their time of occurrence, symptoms were assigned to one of the following observation intervals: acute symptoms (up to 6 months after SBRT), late symptoms (6-24 months after SBRT), and long-term symptoms ( $>2$ years after SBRT). To complete long-term follow-up, we acquired PRO via web, mail, or telephone. The questions focused on current side effects after SBRT and the actual medical condition, including worsening or improvement of symptoms. We used the German items of PROCT$\mathrm{CAE}^{\mathrm{Tm}}$ (Patient-reported Outcome for Common Terminology Criteria for Adverse Events), developed by the NCI (National Cancer Institute) [17]. Also, information about recent imaging results and further treatment procedures after SBRT were reported. To avoid bias and remembering problems, we explicitly asked for incidences during the last week, as Mendoza et al. suggested [23].

During the last 1.5 years of monitoring, we added PRO assessment to our follow-up routine. We sent an invitation to a web-based survey questionnaire to all living patients whose last visit was more than 6 months ago $(n=39)$. Patients living abroad were not contacted. If a patient did not submit the online survey, a paper-based version of the questionnaire was sent via mail. If patients also did not respond to the letter, we phoned them and inquired them personally based on the questionnaire.

\section{Statistics}

Statistical calculations were performed using SPSS Statistics v25 (IBM, USA). If patients received multiple 
treatments, only the first treatment $(n=219)$ was used for the calculation of overall survival (OS) and distant progression (DP). DP was defined as progression outside the lung. Local control (LC) was calculated for all lesions $(n=316)$. OS was calculated from the last treatment day until death or last follow-up; DP/LC from the last treatment day until the date of distant/local progression or until death or last follow-up.

OS, DP, and LC analyses were based on the KaplanMeier method using the log-rank test; Cox regression was used for univariate and multivariate analyses. The following prognostic factors were analyzed: age, gender, Karnofsky Performance Score (KPS), GTV, PTV, PET imaging before treatment, previous chemo, previous external irradiation, number of pulmonary metastases, absence of extrathoracic metastases, controlled primary tumor, primary tumor type, as well as chemotherapy ( $\mathrm{CHT}$ ) between diagnosis of lung metastases and SBRT. We used receiver operating characteristic (ROC) statistics to determine thresholds for grouped variables. A $p$-value $<0.05$ was considered as statistically significant. For patients with multiple follow-ups during one observation interval, we counted the highest CTCAE grade of symptoms/side effects and the lowest KPS.

\section{Results}

\section{Outcomes}

Table 2 provides data on OS, DP, and LC. Median follow-up was 16.5 months (range: $0-14.5$ years). Median OS was 27.6 months (95\% Confidence Interval (CI): 22.8-32.4), median DP was 17.4 months (95\% CI: 9.225.6), mean LC was 135.1 months (95\% CI: 123.5-146.7) as median was not reached.

\section{Prognostic factors}

Univariate analysis (Table 3) showed a significant influence on OS for several prognostic factors. KPS < $90 \%$ was associated with a lower OS $(p<0.001)$, whereas a small GTV $(p=0.002)$ and PTV $(p=0.003)$ showed a significant impact for better OS. The absence of external metastases $(p=0.020), \leq 3$ pulmonary metastases $(p=$ $0.014)$, and controlled primary tumor $(p<0.001)$ also correlate with longer survival. Patients that received higher doses $\left(\mathrm{BED}_{10 \mathrm{iso}}: p=0.001\right.$, and $\mathrm{BED}_{10 \mathrm{PTVmean}}$ :

Table 2 Life table for OS, DP, LC

\begin{tabular}{lllllll}
\hline \multicolumn{7}{c}{ Proportion surviving after } \\
\cline { 2 - 7 } & 1-year & 2-year & 3-year & 4-year & 5-year & 10-year \\
\hline OS & $74 \%$ & $54 \%$ & $39 \%$ & $29 \%$ & $26 \%$ & $17 \%$ \\
DP & $58 \%$ & $46 \%$ & $40 \%$ & $37 \%$ & $34 \%$ & $32 \%$ \\
LC & $92 \%$ & $84 \%$ & $78 \%$ & $77 \%$ & $75 \%$ & $75 \%$ \\
\hline
\end{tabular}

OS Overall survival, DP Distant progression, LC Local control $p=0.007)$ and no chemotherapy between diagnosis and SBRT $(p=0.047)$ lived longer.

In the multivariate analysis, KPS, $\leq 3$ pulmonary metastases, absence of external metastases, and controlled primary remained significant for OS.

For DP, KPS $\geq 90 \%(p<0.001)$, a small GTV ( $p=0.035)$ and PTV $(p=0.046)$, the absence of external metastases $(p<0.001)$, and a controlled primary tumor $(p=0.003)$ were associated with a longer distant progression-free survival.

The multivariate analysis proved KPS, a controlled primary tumor, and the absence of external metastases as significant factors.

Patients with $\leq 3$ pulmonary metastases $(p<0.001)$ had a higher LC rate. Also, the age $(p=0.003)$ influenced LC significantly.

In multivariate analysis, only $\leq 3$ pulmonary metastases remained significant.

\section{Toxicity and PRO}

Documented toxicity was mainly graded 1 or 2 (Tables 4 and 5). During follow-up, physicians reported severe side-effects $\geq$ grade 3 in only $2.9 \%(6 / 207)$ within the first 6 months and in 2.5\% (3/119) after 1 year. Acute symptomatic pneumonitis grade 2 was observed in $9.7 \%$ (20/207), as grade 3 in $0.5 \%$ (1/207). Only new and worsened symptoms after RT are listed in Table 5.

At the time of analysis, $153(153 / 219,69.9 \%)$ patients treated with SBRT were deceased, 15 (15/219, 6.8\%) were seen during regular follow-up visits, and 12 (12/ $219,5.5 \%)$ were living abroad and lost-to-follow-up. The remaining $39(39 / 219,17.8 \%)$ were contacted for PRO assessment. Of the 39 patients, 38 (38/39, 97.4\%) participated in the PRO assessment; 14 participated twice during follow-up. The median time between SBRT and PRO was 53.2 months (range: 2.1 months - 14.5 years).

Patients reported 15 cases of severe side effects grade $\geq$ 3 during PRO assessment (Fig. 1, Table 4). All patients with severe dyspnea $(n=6)$ were diagnosed with chronic obstructive pulmonary disease before SBRT. Four of these were also frequent smoker in the past, one was non-smoker, one had an unknown smoking history. The patient with dysphonia grade 3 had a squamoid carcinoma of the larynx. Out of all, four and three severe side effects were reported each by one single patient.

\section{Discussion}

In our analysis, we evaluated outcomes after highprecision SBRT of 316 lung metastases and determined long-term results, including PRO. We could demonstrate that our rates of LC after SBRT of pulmonary lesions and the low rate of severe toxicity are comparable to those found in the literature $[5,9,16,24-26]$. 
Table 3 -values of univariate and multivariate analyses for OS, DP, and LC. Multivariate analysis was performed with the significant items of univariate analysis

\begin{tabular}{|c|c|c|c|c|c|c|}
\hline & \multicolumn{2}{|c|}{ OS $(n=219)$} & \multicolumn{2}{|c|}{$\mathrm{DP}(n=219)$} & \multicolumn{2}{|c|}{$\underline{L C}(n=316)$} \\
\hline & UVA & MVA & UVA & MVA & UVA & MVA \\
\hline Age at $\mathrm{RT}^{\circ}$ & 0.667 & - & 0.630 & - & $0.003^{*}$ & 0.320 \\
\hline Gender & 0.401 & - & 0.092 & - & 0.220 & - \\
\hline KPS (<90 vs. $\geq 90 \%)$ & $<0.001^{*}$ & $<0.001^{*}$ & $<0.001^{*}$ & $<0.001^{*}$ & 0.844 & - \\
\hline Primary tumor type (NSCLC vs CRC vs. Melanoma vs. Breast) & 0.985 & - & 0.954 & - & 0.437 & - \\
\hline $\mathrm{GTV}^{\circ}$ & $<0.002^{*}$ & 0.439 & $0.035^{*}$ & 0.919 & 0.762 & - \\
\hline $\operatorname{GTV}(<8$ vs $\geq 8 \mathrm{ml})$ & $<0.001^{*}$ & - & $0.005^{*}$ & - & 0.844 & - \\
\hline PTV $^{\circ}$ & $0.003^{*}$ & 0.904 & $0.046^{*}$ & 0.599 & 0.211 & - \\
\hline PTV $(<35$ vs $\geq 35 \mathrm{ml})$ & $<0.001^{*}$ & - & $0.017^{*}$ & - & 0.842 & - \\
\hline Planning PET-CT & 0.264 & - & 0.765 & - & 0.133 & - \\
\hline Number of pulmonary METs ( $\leq 3$ vs. $>3$ ) & $<0.001^{*}$ & $0.014^{*}$ & 0.078 & - & $<0.001^{*}$ & $<0.001^{*}$ \\
\hline Absence extra thoracic MET & $<0.001^{*}$ & $0.020^{*}$ & $<0.001^{*}$ & $<0.001^{*}$ & 0.859 & - \\
\hline Controlled primary tumor & $<0.001^{*}$ & $<0.001^{*}$ & $0.001^{*}$ & $0.003^{*}$ & 0.632 & - \\
\hline CHT between MET diagnosis and SBRT & $0.047^{*}$ & 0.176 & 0.468 & - & 0.097 & - \\
\hline $\mathrm{BED}_{10 \mathrm{iso}}{ }^{\circ}$ & $0.001^{*}$ & 0.289 & 0.413 & - & 0.429 & - \\
\hline $\mathrm{BED}_{10 \mathrm{PTV} \text { mean }}{ }^{\circ}$ & $0.007^{*}$ & 0.468 & 0.439 & - & 0.955 & - \\
\hline Time from primary diagnosis to MET diagnosis ${ }^{\circ}$ & 0.090 & - & 0.985 & - & 0.882 & - \\
\hline Time from primary diagnosis to MET diagnosis ( $<12$ vs. $\geq 12$ months) & 0.884 & - & 0.291 & - & 0.336 & - \\
\hline
\end{tabular}

UVA Univariate analysis, MVA Multivariate analysis, OS Overall survival, DP Distant progression, LC Local control, KPS Karnofsky Performance Score, RT Radiotherapy, CHT Chemotherapy, MET Metastasis, PTV Planning target volume, GTV Gross tumor volume, NSCLC non-small cell lung cancer, CRC colorectal carcinoma, * significant $p$-value, ${ }^{\circ}$ continuous variable

Previously, our group demonstrated prognostic factors in 129 lung cases [27]. The present work comprises a larger group of patients with SBRT treatment and, in particular, the inclusion of PRO assessment. With an LC rate of $78 \%$ after 3 years, we present excellent treatment results known for high-precision SBRT. Also, we could show a very beneficial risk-benefit profile of SBRT among our patient cohort. The evaluation of PRO enabled us to collect comprehensive information about symptoms of patients up to 14 years after SBRT. This distinguishes our work from other studies investigating comparable patient groups with pulmonary metastases.

The OS of the present study is lower compared to other studies and may be explained by applied exclusion criteria. De Rose, for example, only analyzed oligometastatic patients with controlled primary tumor [9] (3-year survival rate: $64 \%$ vs. this study: $39 \%$ ). Navarria et al. excluded patients whose number of metastatic sites was $>5$ and who had a short progression-free survival (3-year survival rate $73 \%$ vs. this study: $39 \%$ ) [8].

Inoue et al. also achieved comparably low 2- and 3year OS rates of 47 and 32\%, respectively. They also evaluated a quite unselected group of patients [28]. Kang et al. showed a five-year OS rate of $29 \%$ [29], which is higher compared to $26 \%$ reported in the present study. However, they excluded patients with metastases in more than one organ.
We showed a benefit in OS for patients with a KPS $\geq 90 \%$, small GTV and PTV, higher BED doses, absence of external metastases, $\leq 3$ pulmonary metastases, and a controlled primary tumor. This prognostic impact could also be shown by other studies [6, 7, 25, 27, 30, 31].

Of all patients, 9.6\% (20/208) developed acute pneumonitis grade 2 , one $(0.5 \%)$ had to be hospitalized (grade $3)$. Late pneumonitis occurred in $6.2 \%(8 / 130)$ and in $1.6 \%(2 / 120)>12$ months after RT. One patient that was treated with RT of the esophagus and regional lymphatic pathways suffered from myocardial infarction, which was treated with PCI (percutaneous coronary intervention). Another patient that received a total dose of 35 Gy in 5 fractions had grade 3 osteoradionecrosis 2.5 years after SBRT. Those toxicity rates are comparable to others $[28$, 32-34].

Dyspnea after SBRT was quite a common complaint $(25.6 \%, 53 / 208)$. However, this is most likely not associated with RT, since many of these patients did not undergo surgery due to chronic obstructive pulmonary disease (COPD), respiratory insufficiency, or an insufficient heart because of other reasons. Smoking was not regularly documented.

$\mathrm{PRO}$ is a measure that becomes more important in oncological treatment. In a study with primary lung cancer patients, Denis et al. [18] showed that regularly reported symptoms by the patient leads to a 6-month 
Table 4 Physician-reported new and worsened side effects during follow-up according to CTCAE classification. PRO data is reported as PROCTCAE and listed separately, hence, not included in the physician reported results

\begin{tabular}{|c|c|c|c|c|c|c|c|c|c|c|c|c|c|c|c|c|c|c|c|c|}
\hline \multirow[t]{2}{*}{ CTCAE grade } & \multicolumn{4}{|c|}{ Pre RT $(n=219)$} & \multicolumn{4}{|c|}{$<6$ months $(n=208)$} & \multicolumn{4}{|c|}{$\begin{array}{l}6-12 \text { months }(n= \\
130)\end{array}$} & \multicolumn{4}{|c|}{$>12$ months $(n=120)$} & \multicolumn{4}{|c|}{$\mathrm{PRO}(n=38)$} \\
\hline & 1 & 2 & 3 & $\overline{4}$ & 1 & 2 & 3 & 4 & 1 & 2 & 3 & 4 & 1 & 2 & 3 & 4 & 1 & 2 & 3 & 4 \\
\hline Pain & $\begin{array}{l}6 \\
(3 \%)\end{array}$ & $\begin{array}{l}4 \\
(2 \%)\end{array}$ & - & - & $\begin{array}{l}14 \\
(7 \%)\end{array}$ & $4(2 \%)$ & $\begin{array}{l}1(< \\
1 \%)\end{array}$ & - & $6(5 \%)$ & $\begin{array}{l}2 \\
(2 \%)\end{array}$ & - & - & $3(3 \%)$ & $\begin{array}{l}6 \\
(5 \%)\end{array}$ & $\begin{array}{l}1 \\
(1 \%)\end{array}$ & - & $\begin{array}{l}9 \\
(24 \%)\end{array}$ & $\begin{array}{l}7 \\
(18 \%)\end{array}$ & - & - \\
\hline Fatigue & $\begin{array}{l}2 \\
(1 \%)\end{array}$ & - & - & - & $\begin{array}{l}21 \\
(10 \%)\end{array}$ & $5(2 \%)$ & - & - & $4(3 \%)$ & $\begin{array}{l}2 \\
(2 \%)\end{array}$ & - & - & $5(4 \%)$ & $\begin{array}{l}3 \\
(3 \%)\end{array}$ & - & - & $\begin{array}{l}9 \\
(24 \%)\end{array}$ & $\begin{array}{l}16 \\
(42 \%)\end{array}$ & - & - \\
\hline Nausea/vomiting & - & - & - & - & $\begin{array}{l}1(< \\
1 \%)\end{array}$ & - & - & - & - & - & - & - & $1(1 \%)$ & - & - & - & $1(3 \%)$ & $3(8 \%)$ & - & - \\
\hline Dermatitis & - & - & - & - & $3(1 \%)$ & - & - & - & $1(1 \%)$ & - & - & - & - & $\begin{array}{l}1 \\
(1 \%)\end{array}$ & - & - & $3(8 \%)$ & $1(3 \%)$ & $\begin{array}{l}1 \\
(3 \%)\end{array}$ & - \\
\hline Hyperpigmentation & - & - & - & - & $3(1 \%)$ & - & - & - & $2(2 \%)$ & - & - & - & - & - & - & - & $2(5 \%)$ & - & - & - \\
\hline Edema & $\begin{array}{l}1(< \\
1 \%)\end{array}$ & - & - & - & $6(3 \%)$ & - & - & - & $5(4 \%)$ & $\begin{array}{l}2 \\
(2 \%)\end{array}$ & - & - & $3(3 \%)$ & $\begin{array}{l}1 \\
(1 \%)\end{array}$ & - & - & $\begin{array}{l}7 \\
(18 \%)\end{array}$ & $\begin{array}{l}7 \\
(18 \%)\end{array}$ & - & - \\
\hline $\begin{array}{l}\text { Osteonecrosis, rib } \\
\text { fracture }\end{array}$ & - & - & - & - & - & - & - & - & - & - & - & - & - & - & $\begin{array}{l}1 \\
(1 \%)\end{array}$ & - & - & - & - & - \\
\hline Sensory deficits & - & $\begin{array}{l}1(< \\
1 \%)\end{array}$ & - & - & - & - & - & - & - & - & - & - & $2(2 \%)$ & - & - & - & $\begin{array}{l}10 \\
(26 \%)\end{array}$ & $\begin{array}{l}5 \\
(13 \%)\end{array}$ & $\begin{array}{l}1 \\
(3 \%)\end{array}$ & $\begin{array}{l}1 \\
(3 \%)\end{array}$ \\
\hline Motor deficits & - & - & - & - & $2(1 \%)$ & - & - & - & - & - & - & - & $2(2 \%)$ & - & - & - & $\begin{array}{l}7 \\
(18 \%)\end{array}$ & $\begin{array}{l}6 \\
(16 \%)\end{array}$ & $\begin{array}{l}2 \\
(5 \%)\end{array}$ & - \\
\hline Weight loss & - & - & $\begin{array}{l}1(< \\
1 \%)\end{array}$ & - & $3(1 \%)$ & - & - & - & $3(2 \%)$ & - & - & - & $5(4 \%)$ & - & - & - & $\begin{array}{l}4 \\
(11 \%)\end{array}$ & $\begin{array}{l}5 \\
(13 \%)\end{array}$ & $\begin{array}{l}1 \\
(3 \%)\end{array}$ & - \\
\hline Fibrosis & $\begin{array}{l}1(< \\
1 \%)\end{array}$ & - & - & - & $\begin{array}{l}25 \\
(12 \%)\end{array}$ & $3(1 \%)$ & - & - & $\begin{array}{l}22 \\
(17 \%)\end{array}$ & $\begin{array}{l}6 \\
(5 \%)\end{array}$ & - & - & $\begin{array}{l}13 \\
(11 \%)\end{array}$ & $\begin{array}{l}2 \\
(2 \%)\end{array}$ & $\begin{array}{l}1 \\
(1 \%)\end{array}$ & - & - & - & - & - \\
\hline Pneumonitis & - & - & - & - & $\begin{array}{l}24 \\
(12 \%)\end{array}$ & $\begin{array}{l}20 \\
(10 \%)\end{array}$ & $\begin{array}{l}1(< \\
1 \%)\end{array}$ & - & $5(4 \%)$ & $\begin{array}{l}3 \\
(1 \%)\end{array}$ & - & - & $1(1 \%)$ & $\begin{array}{l}1 \\
(1 \%)\end{array}$ & - & - & - & - & - & - \\
\hline Dysphagia & $\begin{array}{l}2 \\
(1 \%)\end{array}$ & $\begin{array}{l}2 \\
(1 \%)\end{array}$ & $\begin{array}{l}1(< \\
1 \%)\end{array}$ & - & $3(1 \%)$ & - & $\begin{array}{l}1(< \\
1 \%)\end{array}$ & - & $1(1 \%)$ & $\begin{array}{l}2 \\
(2 \%)\end{array}$ & - & - & $4(3 \%)$ & - & - & - & $\begin{array}{l}10 \\
(26 \%)\end{array}$ & $\begin{array}{l}4 \\
(11 \%)\end{array}$ & $\begin{array}{l}1 \\
(3 \%)\end{array}$ & - \\
\hline Dyspnea & $\begin{array}{l}17 \\
(8 \%)\end{array}$ & $\begin{array}{l}9 \\
(4 \%)\end{array}$ & $\begin{array}{l}1(< \\
1 \%)\end{array}$ & - & $\begin{array}{l}27 \\
(13 \%)\end{array}$ & $\begin{array}{l}23 \\
(11 \%)\end{array}$ & $\begin{array}{l}3 \\
(1 \%)\end{array}$ & - & $5(4 \%)$ & $\begin{array}{l}3 \\
(2 \%)\end{array}$ & - & - & $7(6 \%)$ & $\begin{array}{l}6 \\
(5 \%)\end{array}$ & - & - & $\begin{array}{l}10 \\
(26 \%)\end{array}$ & $\begin{array}{l}8 \\
(21 \%)\end{array}$ & $\begin{array}{l}4 \\
(11 \%)\end{array}$ & $\begin{array}{l}2 \\
(5 \%)\end{array}$ \\
\hline Cough & $\begin{array}{l}15 \\
(7 \%)\end{array}$ & $\begin{array}{l}1(< \\
1 \%)\end{array}$ & - & - & $\begin{array}{l}35 \\
(17 \%)\end{array}$ & $5(2 \%)$ & - & - & $\begin{array}{l}10 \\
(8 \%)\end{array}$ & $\begin{array}{l}2 \\
(2 \%)\end{array}$ & - & - & $\begin{array}{l}15 \\
(13 \%)\end{array}$ & $\begin{array}{l}2 \\
(2 \%)\end{array}$ & - & - & $\begin{array}{l}10 \\
(26 \%)\end{array}$ & $\begin{array}{l}14 \\
(37 \%)\end{array}$ & $\begin{array}{l}1 \\
(3 \%)\end{array}$ & - \\
\hline Xerostomia & $\begin{array}{l}2 \\
(1 \%)\end{array}$ & - & - & - & $3(1 \%)$ & $\begin{array}{l}1(< \\
1 \%)\end{array}$ & - & - & - & - & - & - & $1(1 \%)$ & $\begin{array}{l}1 \\
(1 \%)\end{array}$ & - & - & $\begin{array}{l}11 \\
(29 \%)\end{array}$ & $\begin{array}{l}11 \\
(29 \%)\end{array}$ & - & - \\
\hline Dysphonia & $\begin{array}{l}1(< \\
1 \%)\end{array}$ & - & - & - & $\begin{array}{l}1(< \\
1 \%)\end{array}$ & - & $\begin{array}{l}1(< \\
1 \%)\end{array}$ & - & $2(2 \%)$ & - & - & - & $1(1 \%)$ & - & - & - & $\begin{array}{l}8 \\
(21 \%)\end{array}$ & $\begin{array}{l}4 \\
(11 \%)\end{array}$ & $\begin{array}{l}1 \\
(3 \%)\end{array}$ & - \\
\hline
\end{tabular}

RT Radiotherapy, PRO Patient-reported outcome, CTCAE Common Terminology Criteria for Adverse Events

prolonged OS. Similar results were reported by Basch et al. [19]. In a randomized study with 766 patients, the experimental arm reported PRO data regularly, which also resulted in an improved OS.

As in all retrospective analyses, a limitation is the heterogeneous and poor documentation of clinical data during follow-up. Precisely for this reason, conducting PRO is a relevant addition to regular clinical assessment and leads to the higher completeness of data [35-37]. Especially in cases where long-term side effects of treatment are interesting, and patients are easily lost to follow-up, PRO is an efficient method to quantify symptomatic improvement or worsening [20,21].

When interpreting PRO data, it needs to be considered that the underlying causes of occurring symptoms could not be investigated explicitly. Many cancer patients had lots of different treatments, and side effects cannot be attributed to one therapy. Particularly in cohorts of older patients, this might lead to an increase in reported symptoms in the long-term follow-up due to rising numbers of comorbidities [20]. Another challenge is that symptoms that occurred before treatment but are remembered later when the patients fill out the questionnaire can also lead to misinterpretation. During the PRO assessment, patients often reported higher rates of grade 3 and 4 toxicities. As mentioned earlier, half of these complaints were declared by only two patients indicating the reasonable suspicion of personal sensitivities.

Furthermore, in a regular follow-up visit, physicians usually do not ask patients for all possible side effects; 
Table 5 Comparison of physician-reported outcome after RT and PRO $(n=38)$. In both groups, only new and worsened symptoms after RT are listed

\begin{tabular}{|c|c|c|c|c|c|c|}
\hline \multirow[t]{2}{*}{ CTCAE grade } & \multicolumn{3}{|c|}{ Physician-reported after RT } & \multicolumn{3}{|l|}{ PRO } \\
\hline & $\overline{1 / 2}$ & 3 & 4 & $1 / 2$ & 3 & 4 \\
\hline Pain & $9(24 \%)$ & - & - & $16(42 \%)$ & - & - \\
\hline Fatigue & $10(26 \%)$ & - & - & $25(66 \%)$ & - & - \\
\hline Nausea/vomiting & 1 & - & - & $4(11 \%)$ & - & - \\
\hline Dermatitis & $1(3 \%)$ & - & - & $4(11 \%)$ & $1(3 \%)$ & - \\
\hline Hyperpigmentation & $2(5 \%)$ & - & - & $2(5 \%)$ & - & - \\
\hline Edema & $4(11 \%)$ & - & - & $14(37 \%)$ & - & - \\
\hline Osteonecrosis, rib fracture & - & - & - & - & - & - \\
\hline Sensory deficits & - & - & - & 15 (39\%) & $1(3 \%)$ & $1(3 \%)$ \\
\hline Motor deficits & - & - & - & $13(34 \%)$ & $2(5 \%)$ & \\
\hline Weight loss & $4(11 \%)$ & - & - & $9(24 \%)$ & $1(3 \%)$ & - \\
\hline Fibrosis & $17(45 \%)$ & - & - & - & - & - \\
\hline Pneumonitis & $10(26 \%)$ & - & - & - & - & - \\
\hline Dysphagia & $2(5 \%)$ & - & - & $14(37 \%)$ & $1(3 \%)$ & - \\
\hline Dyspnea & $16(42 \%)$ & - & - & $18(47 \%)$ & $4(11 \%)$ & $2(5 \%)$ \\
\hline Cough & $14(37 \%)$ & - & - & 24 (63\%) & $1(3 \%)$ & - \\
\hline Xerostomia & $1(3 \%)$ & - & - & 22 (58\%) & - & - \\
\hline Dysphonia & - & - & - & $12(32 \%)$ & $1(3 \%)$ & - \\
\hline
\end{tabular}

RT Radiotherapy, PRO Patient-reported outcome, CTCAE Common Terminology Criteria for Adverse Events

they usually concentrate on specific relevant side effects due to limited time. Besides, the PRO patients had a web survey or paper questionnaire at home where they did not have any time pressure to remember but could rethink about their symptoms several times. Questionnaires and web surveys suggest various complaints, so that patients may be more likely to cross more than they would think about in a personal anamnesis. Physicians

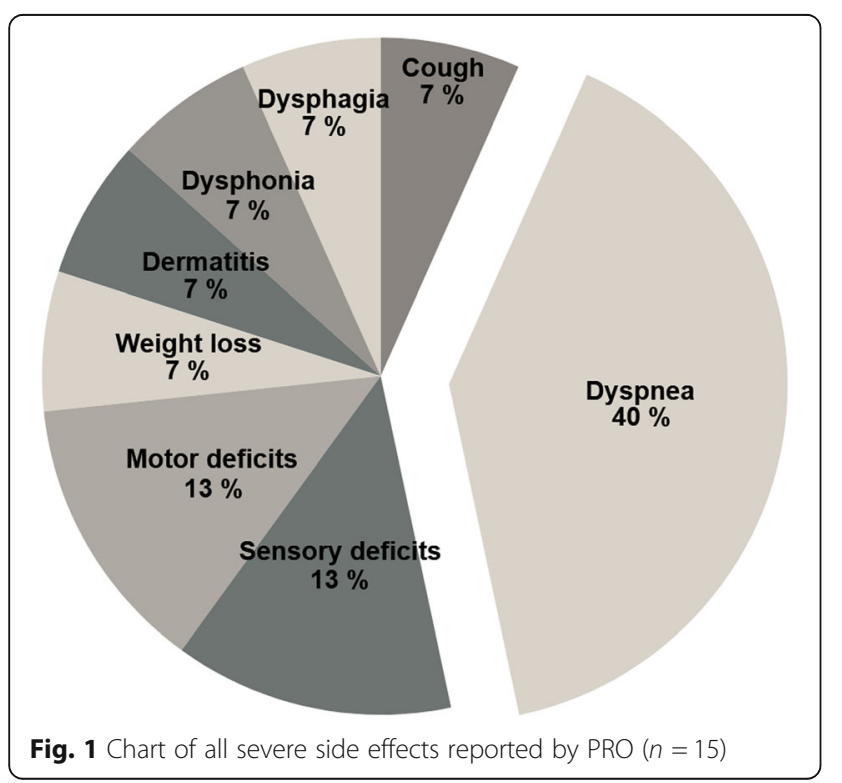

also might tend to filter the patient information and only document treatment toxicities and not everything the patient reported.

The PRO-CTCAE is a standardized classification of symptom measurement, however, the limitation of a direct translation of the patient-reported to a physicianreported symptom remains [38]. It appears that subjective personal sensitivity has a relevant influence on how patients fill out questionnaires. Researchers of the University of Manchester found that toxicity grades of patients with lung RT differ compared to physicianreported results in up to one grade, mostly because patients have a more pessimistic view on their symptoms [39]. The patient-reported view has a higher correlation with the quality of life than physician-documented toxicity [39].

The other aspect one needs to bear in mind when interpreting or comparing the data is that the PRO measures were not taken parallel to physician measures. PRO assessment was additionally conducted when patients were no longer participating in the clinical follow-up workflow to gather information on a missing health status.

A further limitation in our study is that the PRO assessment was only conducted in $17.8 \%$ (39/219); most patients treated with SBRT (69.9\%) were already diseased. However, the response rate of our contacted patients was very high, with $97.4 \%$ (38/39). If implemented earlier or even before therapy, the results would be more 
expressive. Conduction of PRO and clinical assessment at the same time would have increased the comparability of patient-reported and physicians-reported data. Other studies with a prospective approach detected promising benefits of PRO assessment $[18,19]$.

For implementing PRO in clinical routine, it is necessary to develop clear standards for analysis and interpretation. Eventually, parameters, such as necrosis, fibrosis, and pneumonitis need medical imaging or pathological investigation for diagnosis, especially when in a low stage. A questionnaire or interview will not replace imaging; however, PRO data might indicate whether earlier imaging is necessary.

\section{Conclusion}

SBRT is an effective treatment of pulmonary metastases. We could confirm excellent local control and low toxicity rates. PROs improve and complement follow-up care. They are an essential measure in addition to the physician-reported outcomes and should be permanently included in the follow-up workflow. Future research must be conducted regarding the correct interpretation of PRO data. Eventually, the integration of regular PRO into clinical routine combined with high-end RT treatment will further improve patient outcomes.

\section{Acknowledgements}

Not applicable.

\section{Authors' contributions}

RCEG and KAK collected data, RCEG performed the PRO assessment. KAK, RCEG, KMK wrote the manuscript, KAK was responsible for project administration, $\mathrm{HH}$ advised the investigations, $\mathrm{MO}$ discussed results and gave input for manuscript writing, KAK performed statistical analysis, SC advised design and realization of the project. All named authors revised and discussed the manuscript. The authors read and approved the final manuscript.

\section{Funding}

There is no funding.

\section{Availability of data and materials}

The datasets used and/or analyzed during the current study are available from the corresponding author on reasonable request.

\section{Ethics approval and consent to participate}

The local ethics committee of the Medical Faculty of the Technical University München (TUM) approved the study (vote numbers: 257/16, 438/16). All procedures performed in this study involving human participants were in accordance with the ethical standards of the institutional and/or national research committee and with the 1964 Helsinki Declaration and its later amendments or comparable ethical standards. Written informed consent was obtained from all individual participants included in the study.

\section{Consent for publication}

Not applicable.

\section{Competing interests}

The authors declare that they have no financial or non-financial competing interests.

\section{Author details}

'Department of Radiation Oncology, Klinikum rechts der Isar, Technical University of Munich (TUM), Ismaninger Straße 22, 81675 Munich, Germany.
${ }^{2}$ Institute of Radiation Medicine (IRM), Helmholtz Zentrum München, Neuherberg, Germany. ${ }^{3}$ Deutsches Konsortium für Translationale Krebsforschung (DKTK), Partner Site Munich, Munich, Germany. ${ }^{4}$ Division of Thoracic Surgery, Technical University of Munich (TUM), Munich, Germany.

Received: 21 November 2019 Accepted: 14 February 2020

Published online: 19 May 2020

\section{References}

1. Crow J, Slavin G, Kreel L. Pulmonary metastasis: a pathologic and radiologic study. Cancer. 1981:47(11):2595-602.

2. Saito Y, Omiya H, Kohno K, Kobayashi T, Itoi K, Teramachi M, Sasaki M, Suzuki H, Takao H, Nakade M. Pulmonary metastasectomy for 165 patients with colorectal carcinoma: a prognostic assessment. J Thorac Cardiovasc Surg. 2002;124(5):1007-13.

3. Pfannschmidt J, Muley T, Hoffmann $H$, Dienemann H. Prognostic factors and survival after complete resection of pulmonary metastases from colorectal carcinoma: experiences in 167 patients. J Thorac Cardiovasc Surg. 2003; 126(3):732-9.

4. Corbin KS, Hellman S, Weichselbaum RR. Extracranial oligometastases: a subset of metastases curable with stereotactic radiotherapy. J Clin Oncol. 2013:31(11):1384-90.

5. Rusthoven KE, Kavanagh BD, Burri SH, Chen C, Cardenes H, Chidel MA, Pugh TJ, Kane M, Gaspar LE, Schefter TE. Multi-institutional phase I/II trial of stereotactic body radiation therapy for lung metastases. J Clin Oncol. 2009; 27(10):1579-84.

6. Stera S, Balermpas P, Chan MKH, Huttenlocher S, Wurster S, Keller C, Imhoff D, Rades D, Dunst J, Rodel C, et al. Breathing-motion-compensated robotic guided stereotactic body radiation therapy : patterns of failure analysis. Strahlenther Onkol. 2018;194(2):143-55.

7. Rieber J, Streblow J, Uhlmann L, Flentje M, Duma M, Ernst I, Blanck O, Wittig A, Boda-Heggemann J, Krempien R, et al. Stereotactic body radiotherapy (SBRT) for medically inoperable lung metastases-a pooled analysis of the German working group "stereotactic radiotherapy". Lung Cancer. 2016;97:51-8.

8. Navarria P, Ascolese AM, Tomatis S, Cozzi L, De Rose F, Mancosu P, Alongi F, Clerici E, Lobefalo F, Tozzi A, et al. Stereotactic body radiotherapy (sbrt) in lung oligometastatic patients: role of local treatments. Radiat Oncol. 2014; 9(1):91.

9. De Rose F, Cozzi L, Navarria P, Ascolese AM, Clerici E, Infante M, Alloisio M, Testori A, Toschi L, Finocchiaro G, et al. Clinical outcome of stereotactic ablative body radiotherapy for lung metastatic lesions in non-small cell lung Cancer Oligometastatic patients. Clin Oncol (R Coll Radiol). 2016;28(1):13-20.

10. Norihisa Y, Nagata Y, Takayama K, Matsuo Y, Sakamoto T, Sakamoto M, Mizowaki T, Yano S, Hiraoka M. Stereotactic body radiotherapy for oligometastatic lung tumors. Int J Radiat Oncol Biol Phys. 2008;72(2):398-403.

11. Palma DA, Olson R, Harrow S, Gaede S, Louie AV, Haasbeek C, Mulroy L, Lock M, Rodrigues GB, Yaremko BP, et al. Stereotactic ablative radiotherapy versus standard of care palliative treatment in patients with oligometastatic cancers (SABR-COMET): a randomised, phase 2, open-label trial. Lancet. 2019;393(10185):2051-8.

12. Garcia-Cabezas S, Bueno C, Rivin E, Roldan JM, Palacios-Eito A. Lung metastases in oligometastatic patients: outcome with stereotactic body radiation therapy (SBRT). Clin Transl Oncol. 2015;17(8):668-72.

13. Janssen $\mathrm{S}$, Kaesmann L, Rudat V, Rades D. Stereotactic body radiotherapy (SBRT) with lower doses for selected patients with stage I non-small-cell lung Cancer (NSCLC). Lung. 2016;194(2):291-4.

14. Ricardi U, Filippi AR, Guarneri A, Ragona R, Mantovani C, Giglioli F, Botticella A, Ciammella $P$, Iftode $C$, Buffoni $L$, et al. Stereotactic body radiation therapy for lung metastases. Lung Cancer. 2012;75(1):77-81.

15. Thibault I, Poon I, Yeung L, Erler D, Kim A, Keller B, Lochray F, Jain S, Soliman $\mathrm{H}$, Cheung P. Predictive factors for local control in primary and metastatic lung tumours after four to five fraction stereotactic ablative body radiotherapy: a single institution's comprehensive experience. Clin Oncol ( $R$ Coll Radiol). 2014;26(11):713-9.

16. Hof H, Hoess A, Oetzel D, Debus J, Herfarth K. Stereotactic single-dose radiotherapy of lung metastases. Strahlenther Onkol. 2007;183(12):673-8

17. Kirsch M, Mitchell SA, Dobbels F, Stussi G, Basch E, Halter JP, De Geest S. Linguistic and content validation of a German-language PRO-CTCAE-based patient-reported outcomes instrument to evaluate the late effect symptom experience after allogeneic hematopoietic stem cell transplantation. Eur J Oncol Nurs. 2015;19(1):66-74. 
18. Denis F, Lethrosne C, Pourel N, Molinier O, Pointreau Y, Domont J, Bourgeois H, Senellart H, Tremolieres P, Lizee T, et al. Randomized Trial Comparing a Web-Mediated Follow-up With Routine Surveillance in Lung Cancer Patients. J Natl Cancer Inst. 2017;109(9).

19. Basch E, Deal AM, Dueck AC, Scher HI, Kris MG, Hudis C, Schrag D. Overall survival results of a trial assessing patient-reported outcomes for symptom monitoring during routine Cancer treatment. JAMA. 2017;318(2):197-8.

20. Kessel KA, Fischer H, Oechnser M, Zimmer C, Meyer B, Combs SE. Highprecision radiotherapy for meningiomas : long-term results and patientreported outcome (PRO). Strahlenther Onkol. 2017;193(11):921-30.

21. Kessel KA, Fischer H, Vogel MM, Oechsner M, Bier H, Meyer B, Combs SE. Fractionated vs. single-fraction stereotactic radiotherapy in patients with vestibular schwannoma : hearing preservation and patients' self-reported outcome based on an established questionnaire. Strahlenther Onkol. 2017 193(3):192-9.

22. Kessel KA, Vogel MM, Alles A, Dobiasch S, Fischer H, Combs SE. Mobile app delivery of the EORTC QLQ-C30 questionnaire to assess health-related quality of life in oncological patients: usability study. JMIR Mhealth Uhealth. 2018;6(2):e45.

23. Mendoza TR, Dueck AC, Bennett AV, Mitchell SA, Reeve BB, Atkinson TM, Li $Y$, Castro KM, Denicoff A, Rogak $L$, et al. Evaluation of different recall periods for the US National Cancer Institute's PRO-CTCAE. Clin Trials. 2017; 14(3):255-63.

24. Wulf J, Baier K, Mueller G, Flentje MP. Dose-response in stereotactic irradiation of lung tumors. Radiother Oncol. 2005;77(1):83-7.

25. Tanadini-Lang S, Rieber J, Filippi AR, Fode MM, Streblow J, Adebahr S, Andratschke N, Blanck O, Boda-Heggemann J, Duma M, et al. Nomogram based overall survival prediction in stereotactic body radiotherapy for oligometastatic lung disease. Radiother Oncol. 2017;123(2):182-8.

26. Rieber J, Abbassi-Senger N, Adebahr S, Andratschke N, Blanck O, Duma M, Eble MJ, Ernst I, Flentje M, Gerum S, et al. Influence of institutional experience and technological advances on outcome of stereotactic body radiation therapy for Oligometastatic lung disease. Int J Radiat Oncol Biol Phys. 2017;98(3):511-20.

27. Borm K, Oechsner M, Schiller K, Peeken JC, Dapper H, Munch S, Kroll L, Combs SE, Duma MN. Prognostic factors in stereotactic body radiotherapy of lung metastases. Strahlenther Onkol. 2018;194(10):886-93.

28. Inoue T, Oh RJ, Shiomi H, Masai N, Miura H. Stereotactic body radiotherapy for pulmonary metastases. Prognostic factors and adverse respiratory events. Strahlenther Onkol. 2013;189(4):285-92.

29. Kang JK, Kim MS, Kim JH, Yoo SY, Cho CK, Yang KM, Yoo HJ, Seo YS, Lee $\mathrm{DH}$, Kang HJ, et al. Oligometastases confined one organ from colorectal cancer treated by SBRT. Clin Exp Metastasis. 2010;27(4):273-8.

30. Janssen S, Kaesmann L, Rudat V, Rades D. A scoring system for predicting the survival prognosis of patients receiving stereotactic body radiation therapy (SBRT) for 1-3 lung metastases. Lung. 2016;194(4):631-5.

31. Zhang $Y$, Xiao JP, Zhang HZ, Yin WB, Hu YM, Song YX, Zhang K, Liao ZX, L $Y X$. Stereotactic body radiation therapy favors long-term overall survival in patients with lung metastases: five-year experience of a single-institution. Chin Med J. 2011;124(24):4132-7.

32. Baba F, Shibamoto Y, Tomita N, Ikeya-Hashizume C, Oda K, Ayakawa S, Ogino $\mathrm{H}$, Sugie C. Stereotactic body radiotherapy for stage I lung cancer and small lung metastasis: evaluation of an immobilization system for suppression of respiratory tumor movement and preliminary results. Radiat Oncol. 2009;4:15.

33. Nuyttens JJ, van der Voort van Zyp NC, Verhoef C, Maat A, van Klaveren RJ, van der Holt B, Aerts J, Hoogeman M. Stereotactic body radiation therapy for oligometastases to the lung: a phase 2 study. Int J Radiat Oncol Biol Phys. 2015;91(2):337-43.

34. Xiong W, Xu Q, Xu Y, Sun C, Li N, Zhou L, Liu Y, Zhou X, Wang Y, Wang J, et al. Stereotactic body radiation therapy for post-pulmonary lobectomy isolated lung metastasis of thoracic tumor: survival and side effects. BMC Cancer. 2014;14:719.

35. Barbera L, Lee F, Sutradhar R. Use of patient-reported outcomes in regional cancer centres over time: a retrospective study. CMAJ Open. 2019;7(1):E101-8.

36. Bingham CO 3rd, Gaich CL, DeLozier AM, Engstrom KD, Naegeli AN, de Bono S, Banerjee P, Taylor PC. Use of daily electronic patient-reported outcome (PRO) diaries in randomized controlled trials for rheumatoid arthritis: rationale and implementation. Trials. 2019;20(1):182.
37. Lavallee DC, Chenok KE, Love RM, Petersen C, Holve E, Segal CD, Franklin PD. Incorporating patient-reported outcomes into health care to engage patients and enhance care. Health Aff (Millwood). 2016;35(4):575-82.

38. Atkinson TM, Ryan SJ, Bennett AV, Stover AM, Saracino RM, Rogak LJ, Jewell ST, Matsoukas K, Li Y, Basch E. The association between clinician-based common terminology criteria for adverse events (CTCAE) and patientreported outcomes (PRO): a systematic review. Support Care Cancer. 2016; 24(8):3669-76.

39. Christodoulou M, McCloskey P, Stones N, Bayman N, Burt P, Chittalia A, Harris M, Lee L, Pemberton L, Sheikh $H$, et al. Investigation of a patient reported outcome tool to assess radiotherapy-related toxicity prospectively in patients with lung cancer. Radiother Oncol. 2014;112(2):244-9.

\section{Publisher's Note}

Springer Nature remains neutral with regard to jurisdictional claims in published maps and institutional affiliations.
Ready to submit your research? Choose BMC and benefit from:

- fast, convenient online submission

- thorough peer review by experienced researchers in your field

- rapid publication on acceptance

- support for research data, including large and complex data types

- gold Open Access which fosters wider collaboration and increased citations

- maximum visibility for your research: over $100 \mathrm{M}$ website views per year

At BMC, research is always in progress.

Learn more biomedcentral.com/submissions 